DOI: 10.2478/auseur-2020-0001

\title{
How Do You Want Me to Address You? - The Macedonian Name Dispute Resolved
}

\author{
Krisztián MANZINGER \\ $\mathrm{PhD}$, Senior Lecturer \\ Faculty of Law, Károli Gáspár University of the Reformed Church in Hungary, Budapest \\ e-mail: manzinger.krisztian@kre.hu
}

\begin{abstract}
The Macedonian name dispute, a political debate between Greece and the current Republic of North Macedonia, arose after the break-up of the multi-ethnic Yugoslavia. The issue was overpoliticized for the societies of both countries. The international community followed the dispute, yet it did not exercise any pressure on Greece to cede in a debate seen by many as the stronger bullying the weaker. A breakthrough became achievable when political forces interested in the resolution came into power in both countries in the mid-2010s. The Prespa Agreement, signed in 2018, offered a mutually acceptable resolution and opened the way for North Macedonia to enter the NATO and to the opening of accession talks with the EU in March 2020.
\end{abstract}

Keywords: name dispute, Greece, Macedonia, North Macedonia, Prespa Agreement, nation building

On 27 March 2020, the NATO welcomed its $30^{\text {th }}$ member state. The North Atlantic Treaty Organization is a military alliance founded in 1949 against attacks from the outside. It welcomes new members from time to time. Both Hungary and Romania are member states since 1999 and 2004 respectively. What made the entry of the $30^{\text {th }}$ member state, namely North Macedonia, a special occasion was not the military importance of the country but the prolonged process of entry. Skopje joined the Partnership for Peace programme - the 'antechamber' of NATO membership in 1995, yet it took another 25 years to become a full-fledged member. The reason behind it was not any kind of unpreparedness of the Balkan state but a political issue, a 'name dispute' with Greece. In this paper, we will discuss this dispute.

In order to do this, we will examine the details of this unique international case, focusing on the origins of the dispute, outlining the sensitivities of the parties and the contribution of the international community. First, we will discuss homonymy to point out that cross-border regions bearing closely the same names are not rare. After that, we will present the Greek and the Macedonian positions and their relations. Later, we will examine the international community's role in resolving the name 
dispute to measure whether the international community could have fostered the solution earlier or at least if it tried to contribute to the denouement of the dispute at all. We will pay a detailed attention to the contents of the Prespa Agreement, signed in 2018 , and its ratification process before the concluding remarks.

\section{Homonymy}

Since geographic and political boundaries often differ, there are territories divided between states bearing the same or very similar denominations. On the north-western borders of Romania, one can find geographical-administrative regions named Bihor/ Bihar, Satu Mare/Szatmár, and Maramureş/Máramaros, partly belonging to Romania and to the neighbouring Hungary and Ukraine. These territories were counties of Hungary before the Treaty of Trianon in 1920, but the Romanian administration did not erase the names. Similarly, the Duchy of Limburg was divided between the Netherlands and Belgium in 1830, and there is even today a province in both countries bearing this name.

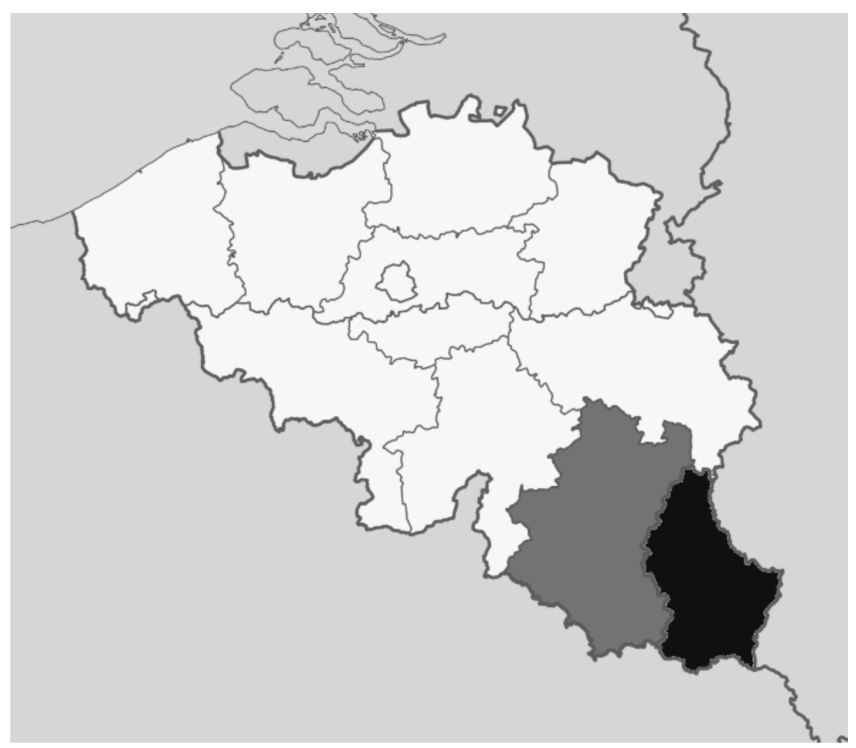

Figure 1. The Grand Duchy of Luxembourg in black and Luxembourg Province in Belgium in dark grey

The case of Luxembourg (see Fig. 1) is probably more interesting since it is similar to that of Macedonia. The Grand Duchy of Luxembourg lost territories to France, Prussia (today Germany), and Belgium between 1659 and 1839, however, still maintaining its independence between the two Western European powers. 
The former Luxembourg territories attached to France and Germany were absorbed into other administrative units, while the one under Belgian administration has become a Wallonian region named 'Luxembourg'. Its name has neither prefixes nor geographic or political modifiers, and the region uses a flag coloured the same way and a closely identical symbol to the coat of arms of Luxembourg. This has never caused any tensions between the two Western European states.

Debated historical experiences reflected in different naming, however, are not rare either. For instance, in Slovakian, Hungary has two names: one for the common state until 1918, Uhorsko, and another for Hungary after the separation, Mad'arsko. Only the Czech and the Serbian use exactly the same distinction, while there is no difference in Hungary's name in any other languages. Similar differentiation, nevertheless, exists in Romanian with the distinction between maghiari and unguri (both meaning Hungarians), where maghiari refers to ethnic Hungarians in Romania, for instance, and unguri to Hungarian citizens; yet, the Hungarian state both before and after the Great Union Day of 1 December 1918, i.e. indifferent whether it contained Transylvania or not, is called Ungaria in Romanian. These distinctions show political agenda and diverging understandings of the past and present but are not meant to provoke international controversy, i.e. to oblige other states to accept such interpretations. This makes a difference to the former name dispute between Greece and Macedonia.

\section{Macedonia}

The territory of geographic Macedonia was divided in 1912/1913. The new rulers of the territory, Bulgaria, Greece, and, until the end of WWII, Serbia, exercised assimilatory policies to prevent the development of a Macedonian national consciousness and to turn the inhabitants into Bulgarians, Greeks, and Serbs respectively. In this article, we cannot enter into details on the development of the Macedonian national feeling; however, it is to be stressed that the Yugoslav policy applied after 1944 in Tito's Yugoslavia eventually led to the birth of a modern nation. Since then, 'Macedonian' has had various meanings.

A 'Macedonian' is someone from any of the three regions of Macedonia who chooses to develop a regional Macedonian identity regardless of his/her own citizenship or ethno-national belonging. Thus, Aleksandar from Skopje, Mehmet from Tetovo, Jane from Petrich, Asparuh from Blagoevgrad, Yorios from Thessaloniki, and Atanas from Florina are all Macedonians. Thus, while Aleksandar, Jane, and Atanas are all Macedonians sharing the same (ethno) national feelings, only Aleksandar and Mehmet are Macedonians by citizenship, while Asparuh and Yorios are regionally Macedonians who have Bulgarian and Greek (...) citizenships respectively. (Daskalovski 2013) 
We can distinguish various 'Macedonias': the geographic one, the country currently named North Macedonia, the Greek region of Macedonia, and Pirin Macedonia of Bulgaria. They all belong to the geographic Macedonia, as shown in Figure 2.

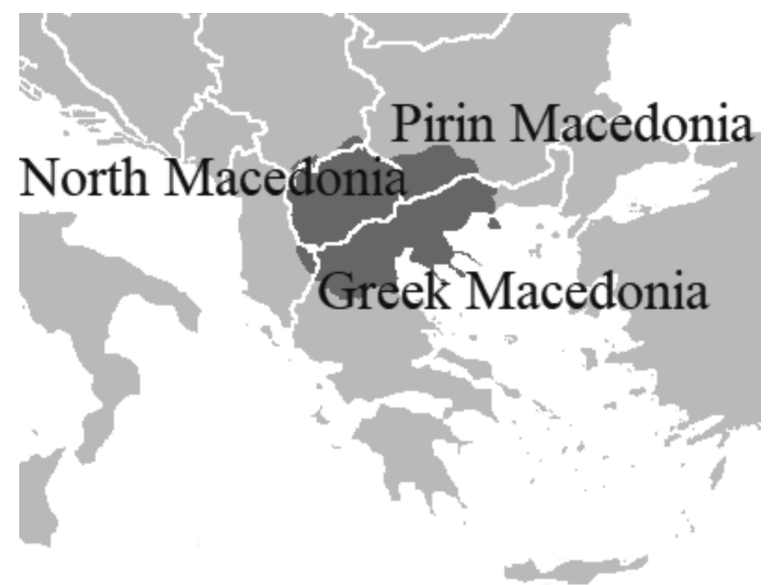

Figure 2. 'Macedonias' (own editing)

In this article, we will not enter into details on the history or content of the Macedonian identity, on linguistic questions, or the international relationships to Bulgaria or Serbia. We will focus solely on the sensitivities connected to and the resolution of the name dispute with Greece. While not taking a stance in the name dispute, for purely pragmatic reasons, in this paper we will use the name 'Macedonia' for the current Republic of North Macedonia and distinguish with modifiers any other use, i.e. Greek Macedonia, the ancient Macedonian kingdom, etc.

\section{The Importance of Macedonia to Greece}

Greece is a country with a complex history, rooted in antiquity but deeply characterized by a centuries-long Ottoman occupation and the division and regression of the Greek ethnic territory - except for the territories belonging to Greece today. When the modern country became independent in 1821 and internationally recognized in 1830, the leaders realized their dependence on the good will and the support of the great powers, not only in the mere existence of the country but also in conquering Greek-inhabited territories beyond the borders. ${ }^{1}$ Greek expansionist foreign policy, with the exception of the incorporation of the Dodecanese in 1947 and the failed annexation attempt of Cyprus in 1974, lasted until 1922, the Turkish military victory over the Greek forces in Asia Minor and Thrace.

1 Only a quarter of the Greeks lived within the 1830 borders of Greece. 
Greece, and probably more importantly the Greek public opinion, had mainly two problems with naming the northern neighbour state Macedonia; one was related to the interconnected question of possible territorial claims and the existence of an (unrecognized) Slavic-speaking minority in Greek Macedonia, while the other arose from questioning ancient Macedonia’s cultural heritage being solely Greek heritage.

Greek Macedonia became part of Greece in 1913, after the First Balkan War. Geographic Macedonia had been divided into two vilayets in the last years of the Ottoman rule: the vilayets of Monastir and Salonica. ${ }^{2}$ In 1913, the southern part of the latter became part of Greece, while the northern was ceded to Serbia. Before the Greek annexation, ethnic identity was very fluid in the ethnically diverse region (Agelopoulos 1995). The share of ethnic Greeks considerably grew due to the population transfers of the 1910s and 1920s; also, the ethnic Greeks evacuated from Turkey after the Treaty of Lausanne in 1923 and were in great part settled into Northern Greece, gradually leading to an ethnic Greek majority there by the end of the 1920s. ${ }^{3}$

Making the country Greek has been a long-standing desire of the Greek political élite. After conquering new territories, Greece invented new names to several villages throughout the state to create and penetrate historical consciousness. Greek intellectuals wanted to erase all denominations linked to the dark periods of Greek history or those that were simply Slavic or Albanian (Liakos 2008: 230-235). This place name change process lasted until the 1960s, interlinking with the denial of the multi-ethnic composition of Greek Macedonia (Bintliff 2003: 138).

The population transfers of the 1910s and 1920s did not result in an ethnically homogenous region: a significant part of the population in Greek Macedonia has remained Slav-speaking until today. Under Article 9 of the Treaty between the Principal Allied and Associated Powers and Greece, signed on 10 August 1920 at Sèvres, Athens committed itself to provide adequate facilities for ensuring instruction in mother tongue for non-Greek-speaking pupils in primary schools functioning on territories transferred to Greece after 1 January 1913. ${ }^{4}$ Since this provision covered the Slavic-speaking population of Macedonia, an ABC-book was published in the Macedonian central dialect in 1925. Nevertheless, that has never been introduced into public schools in Greece (Vankovska 2010: 441). The members of the Slavic-speaking minority experienced the worst circumstances under Ioannis Metaxas's dictatorship (1936-1941), yet the community is still unrecognized as a minority in Greece today. ${ }^{5}$

2 The Salonica Vilayet had some one million inhabitants, and the numbers of Orthodox and Muslim believers were roughly the same (Karpat 1985: 168-169).

3 Between 1912 and 1925, some 480,000 Turks left Greece and 1,290,000 Greeks arrived to Greece, mostly to Greek Macedonia and Thrace (Balogh 2002: 44).

4 Treaty between the Principal Allied and Associated Powers and Greece. In: The American Journal of International Law 15(2) Supplement: Official Documents (April 1921), 165.

$5 \quad$ Greece recognizes only the 'Muslim' minority under the Treaty of Lausanne, 1923. 
During the civil war after WWII, Slav-speaking Macedonians mostly fought on the Greek communist side, who promised them equal rights. With the defeat of the communist forces, many Slav-speaking Macedonians left Greece, settling in Yugoslavia or in other Central European communist states. ${ }^{6}$ The post-war Greek governments denied Slav-speaking refugees the right to return and confiscated their properties but also violated the human rights of the Slavic minority remaining in Greece. These resulted in the rise of a nationalist sentiment in Yugoslav Macedonia, which found expression in schoolbooks and the propagation of a Macedonian identity (Zeri-Tsekeris-Tsekeris 2018: 4).

In Greece, many consider Macedonian identity the result of 'Yugoslav Communist abstractions'. Thus, Athens rejects Macedonian national consciousness within Greece as 'such an ethnic consciousness is an artificial construct created by a hostile neighbour with territorial aspirations' and prefers to identify the Slavic-speaking inhabitants of Greek Macedonia as Slavophone Greeks instead of ethnic Macedonians (Hatzidimitriou 1993: 339-340). According to the Greek argumentation, the nonGreek bilingual inhabitants of Northern Greece were removed from the country during the population exchanges in the first decades of the $20^{\text {th }}$ century, and by implication those bilinguals who remained have Greek national consciousness. ${ }^{7}$

From the very beginning of the name dispute, the other problematic issue for Athens was the perceived challenge to ancient Macedonian cultural heritage belonging solely to Greece. The Macedonian and Hellenistic past have been important and essential parts of Greek history for generations (Zeri-Tsekeris-Tsekeris 2018: 5). For the Greek social imaginary, the 'myth of Greekness' is based on the ideological domination of the cult of antiquity without reference to the modern value system (individual responsibility, respect for reason and difference, the rule of law, human rights, civic liberties, etc.). This resulted, in the case of Macedonia, in the non-recognition of the right to self-determination (Zeri-Tsekeris-Tsekeris 2018: 9-12). ${ }^{8}$ Calling into question the emblematic part of the Greek cultural and historical heritage, the time of Alexander the Great has been unacceptable for Athens, even if there was little evidence for such intentions in Macedonia before the 'Antiquization' of the 2010s.

6 In Romania, the main camp to host refugees was set up in Tulgheş/Gyergyótölgyes in Harghita County, in former Hungarian Army barracks. Many of the Greek refugees later returned to Greece,

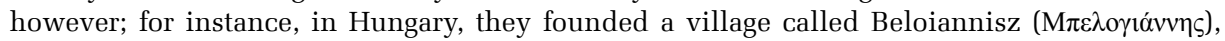
where, at the census of 2011 , some $27 \%$ of the population still declared Greek ethnicity.

7 The Macedonian Affair - A Historical Review of the Attempts to Create a Counterfeit Nation. 1995. Institute of International and Strategic Studies in Athens. http://www.hri.org/docs/affair. html. Accessed on: 14 April 2020. On Greek Macedonian identity, see: Manos 2010. On Being Macedonian: Social and Cultural Constructions of Identity in Greek Macedonia. In: Stefanidis, Ioannis D.-Vlasidis, Vlasis-Kofos, Evangelos (eds), Macedonian Identities Through Time Interdisciplinary Approaches. Thessaloniki: Epikentro. 258-272.

8 This lack results in incapacity for self-reflexivity and the prevalence of defensive and phobic attitudes towards the Others, the present, and the future as well as of ethnocentric and xenophobic myths. The imaginary structure of the Greek society thus casts its heavy shadow on the reformist culture's anticipation of the modern European humanistic values and Enlightenment thought. 
During the Cold War, there was no Macedonian problem: between 1944 and 1991, there existed a country within the federal Yugoslavia, the Socialist Republic of Macedonia, and Greece not only did not object to this, but by establishing a consulate in Skopje, bearing the name of the 'host-republic', Athens accepted the existence of an administrative unit within Yugoslavia under its federal constitution of 1974 (Vankovska 2010: 442). Some argue that the concept of uti possidetis, granting international recognition to previously existing borders of newly independent states - mostly but not exclusively former colonies -, can be extended by analogy to the question of the name of a state (Messineo 2012: 175). Greece, however, did not share this opinion.

Since nation building is of utmost importance to Athens, resulting in the glorification of national unity, any manifestation of 'Macedonianness' (Macedonian identity) was impeded for decades. The development of that identity, however, as complementary to the Greek one, became a major aim for the political élite in the 1980s parallel to the developments in neighbouring Yugoslavia. ${ }^{9}$ The [Greek] Museum of the Macedonian Struggle was inaugurated in 1982 in Thessaloniki by the president of the state in a symbolic building, that of the former Greek Consulate before 1912. The Museum intends 'to preserve and disseminate the memory of the struggles of Hellenism for the liberation of Macedonia, in particular the Macedonian Struggle, and the scientific study of the modern and contemporary history of Macedonia'. ${ }^{10}$

A year later, in 1983, a volume titled Macedonia: 4000 Years of Greek History

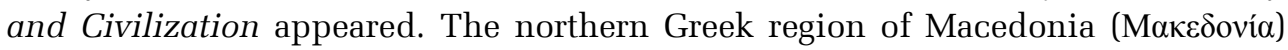
was named as such in 1987, and the region has been using the Vergina Sun as an unofficial symbol since 1993. Also in 1993 the Greek government included the word 'Makedonia' in the name of the Thessaloniki Airport. In the first half of the 1990s, the state-driven commemoration culminated in the cult of Pavlos Melas, one of the first iconic figures of the Macedonian Struggle, the $90^{\text {th }}$ anniversary of whose death was celebrated on 13 October 1994 (Balogh 2011: 210).

As numerous evidence show, the name dispute was not an issue solely generated for political purposes as the overwhelming part of the Greek society is backing the 'defence' of the Greek heritage from the Slavic neighbour. For instance, in 1992, over a million Greeks took to the streets in protest against the name of the newly independent northern neighbour. Also in 1992, with the exception of the Greek Communist Party, all Greek parliamentary parties agreed that they would never recognize the country under any name containing the word 'Macedonia' or any

9 The Greek 'Macedonian revival' became inevitable when Yugoslavia started to approach to an end after Tito's death since the possibility of an independent Slavic Macedonia, worrying Athens, appeared on the horizon.

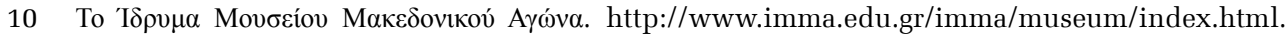
Accessed on: 14 April 2020. 
derivation of that (Kofos 2001: 239). In public discourse, for Greeks, the name chosen to describe the neighbouring state is usually 'Skopje' and its inhabitants 'Skopjans' (Kalampalikis 2019: 102-107). This clear popular stance thus impeded every step forward between 1991 and 2015, when the centre-right New Democracy (ND) and the centre-left Panhellenic Socialist Movement (PASOK) rotated in power.

\section{Identity in Macedonian Politics}

In 1991, the newly independent Macedonia was in an extremely difficult situation. Internally, it had a weak economic base, almost non-existent democratic traditions emerging from a communist political culture, and tense interethnic relations, while externally it was surrounded by sometimes hostile or at least not friendly neighbours (Vankovska 2010: 447). The name dispute with Greece added to these problems, significantly worsening the already problematic environment. The situation was further deteriorated by the withdrawal of the Yugoslav Army that left Macedonia practically without necessary weaponry for even self-defence (Vankovska 2010: 453), and the Greek blockade in 1994-1995 imposed to 'resolve' the name dispute, occurring at the same time with the UN embargo on Yugoslavia. These problems obviously prevented the story of post-socialist and independent Macedonia to become a successful one and had a major influence on the grievances of creating a collective identity for Macedonian citizens deeply divided both politically and ethnically.

With a bipartisan ethnic Macedonian political system, there was little chance for overcoming identity problems found at the core of the name dispute. Since the use of the name 'Macedonia' has been crucial for the ethnic Macedonian electorate, neither the leftist nor the rightist parties were for a long time in the position of giving up the firm stance for the constitutional name Republic of Macedonia (Fidanovski 2018: 20). What made the situation even more fragile was the large share of the ethnic Albanian population. They had long-lasting difficulties with social integration into the Macedonian society, culminating in the uprising of 2001. Ethnic Albanians always showed indifference to the name dispute and urged for a resolution permitting the country to start accession talks with the EU and the NATO. This was particularly the case after Albania became a NATO member state in 2009. Sometimes ethnic Albanians openly advocated for an ethnically neutral denomination, such as Illyro-Macedonia (Vankovska 2010: 438, 455).

Even before independence, there were signs that irredentism can emerge in Macedonia, providing a tool to Greece: in October 1989, a demonstration was held in Skopje calling for the 'reunification' of Macedonia, and slogans such as 'Thessaloniki is ours' were publicly stated (Kofos 2001: 236). In 1991, the newly independent Macedonia chose Vergina Sun, an ancient symbol tentatively interpreted as the symbol of the ancient Kingdom of Macedonia, as the national 
symbol displayed on its new flag. The Greek response was firm: non-recognition of the state and economic blockade partly coinciding in time with the UN-imposed embargo on Yugoslavia practically locking down Macedonian borders. The situation was resolved by the Interim Accord of 1995, in which Skopje agreed to change its national flag, the removal of the Vergina Sun from it, and to amend its constitution to include an explicit pledge of no territorial claims to the rest of the historical region of Macedonia (Fidanovski 2018: 18).

With the ongoing name dispute, to be detailed in the next chapter, things did not alter significantly until around 2010. Then, after the refusal of Macedonia's accession to the NATO in 2008, the rightist government in power started a policy called 'antiquization' (антиквизација). The chief party of the government was one of the main pillars of the bipartisan Macedonian political system, the Democratic Party for Macedonian National Unity (VMRO-DPMNE), which considers itself the ideological successor of the early-20 $0^{\text {th }}$-century independence movement of Internal Macedonian Revolutionary Organization (VMRO). Its leader, then Prime Minister Nikola Gruevski, also held secret talks with Greece, without the formal UN participation, during which the Macedonian government was ready to accept such names as Northern Macedonia or Upper Macedonia despite turning such variations down previously as completely unacceptable ones (Fidanovski 2018: 38).

Parallel to the secret talks, the 'antiquization' started to turn history into social experience. The Skopje 2014 programme, launched in 2010, resulting in more than 130 structures in the capital city, was one of the main pillars of the 'antiquization'. The programme was highly criticized for the controversial and questionable structures, their placing, and for the lack of transparency in finance. The most problematic criticism, however, was due to the attempts to build a pseudo-'antique' style and to 'recreate' the image of a city that never existed (Stefanovska-Koželj 2012: 97). The 'antiquization' aimed both at getting rid of the Yugoslav architectural heritage constructed after the 1963 earthquake and at 'creating' a historical city rooted in antiquity. Thus, 'Skopje 2014' could be understood as a constructed portrayal of a false Macedonian history, pointedly and intentionally obfuscating traces of the country's collective socialist past in favour of a hero narrative rooted in the era of Alexander the Great (Bitter-Weber 2018: 39-48).

The 'antiquization' was very counterproductive for Macedonia. Obviously, in various ways, it was about rivalry with Greece. For instance, a 22-metre high statue of Alexander the Great was placed in Skopje's main square, 'dethroning' thus 'the' Alexander the Great statue of Thessaloniki. On 8 September 2011, at the $20^{\text {th }}$ anniversary of independence, the National Institution Museum of the Macedonian Struggle for Independence was opened, with a mission to 'present the historical, cultural and revolutionary traditions of Macedonia and the Macedonian people in their perennial struggle to create a national state on the Balkans' and to 'display all ordeals suffered by the Macedonian people in the exercise of its libertarian vision, 
the original idea of the revolutionary struggle for the liberation of Macedonia, unification and the creation of an independent Macedonian state'. ${ }^{11}$

In the mid-2010s, however, significant changes happened in the Macedonian society: in the period of 2014-2016, a cross-ethnic mobilization prevailed over the previous ethnic division to articulate the common interests of the civil society (Ahn 2017: 40-53), and due to the social dissatisfaction the leftist Social Democratic Union of Macedonia (SDM) came back into power in 2017. With these alterations, Skopje put an end to the stalemate on the name talks and sought for a constructive dialogue with the Greek government led by far-left Syriza. The talks started in February 2018 under the aegis of both the United Nations (UN) and the EU.

\section{The Name Dispute}

Besides the above-mentioned circumstances, the break-up of Yugoslavia also came in a time of consecutive elections and political instability in Greece, determining profoundly the Greek political élite's view on the regional challenges emerging in the Balkans (Voskopoulos 2006: 69). These prevented Athens to define policies in line with its European partners on the growingly unstable Balkans.

In the early 1990s, Macedonia struggled for international recognition in the neighbourhood of the Yugoslav wars and an EU and NATO member state Greece denying its existence. The international isolation of Macedonia eased late in 1993 as leading powers announced they would enter into diplomatic relations with the state. To defend its position, in February 1994, Greece imposed a blockade, except for food and medicine, on Macedonia lasting until the fall of 1995. The embargo resulted first in the pivotal role of the international community in mediating the Interim Accord in 1995.

On the Macedonian side, the Interim Accord required, as mentioned above, among others, the change of the national flag, while on the Greek side to restrain from hampering the neighbouring country's attempts for global integration under the name Former Yugoslav Republic of Macedonia (FYROM), accepted by the UN in 1993. The Accord also obliged both parties to maintain friendly relations. According to Article 5(2): '[t]he Parties shall co-operate with a view to facilitating their mutual relations notwithstanding their respective positions as to the name of the Party of the Second Part' (i.e. Macedonia). Furthermore, Greece agreed to carry out normal trade relations with Macedonia and not to obstruct normal trade and commerce between Macedonia and third parties. According to Article 11(1), Greece undertook the obligation not to object Macedonia's admission to international organizations so long as that happens under the 'provisional' name. The Accord came just in time:

11 History of the Museum. https://www.mmb.org.mk/index.php/en/2016-03-22-12-58-17/history. Accessed on: 14 April 2020. 
with the ending of the Bosnian war in 1995, international interest in the dispute waned substantially (Fidanovski 2018: 24).

For the international community, the Greek-Macedonian name dispute was a unique problem. Due to the overall fragility of the Balkans and the unquestionable Greek popular support for the case, the international community paid attention to the issue from the very beginning; however, many viewed the situation as the stronger state was 'bullying' the weaker one.

Obviously, international law does not regulate such a situation. The international order, according to the Article 1(2) of the Charter of the United Nation (UN), is based 'on respect for the principle of equal rights and self-determination of peoples'. The UN General Assembly adopted a declaration in 1970 on the Principles of International Law, Friendly Relations, and Co-operation among States in Accordance with the Charter of the United Nation, which states the followings:

The principle of sovereign equality of States

All States enjoy sovereign equality. They have equal rights and duties and are equal members of the international community, notwithstanding differences of an economic, social, political or other nature.

In particular, sovereign equality includes the following elements: (...)

(b) Each State enjoys the rights inherent in full sovereignty;

(c) Each State has the duty to respect the personality of other States; (...)

(e) Each State has the right freely to choose and develop its political, social, economic and cultural systems;

(f) Each State has the duty to comply fully and in good faith with its international obligations and to live in peace with other States. (...)

When Macedonia applied for UN membership in 1992, it did so under the constitutional name of Republic of Macedonia. Despite the protests of the government in Skopje against the crystalizing name of Former Yugoslav Republic of Macedonia (FYROM) in early 1993, the UN General Assembly adopted the accession under that name and not the constitutional one, with its Resolution No $47 / 225$. However, it accentuated that the name is provisional and applied only for purposes within the UN. According to Macedonian legal opinions, the decision constituted a violation of Art. 4(1) of the Charter of the UN, under which '[m] embership in the United Nations is open to all other peace-loving states which accept the obligations contained in the present Charter and, in the judgment of the Organization, are able and willing to carry out these obligations', creating thus an unprecedented requirement for Macedonia to negotiate its self-identification ${ }^{12}$ and

12 A similar example was that of Austria declaring independence in October 1918 under the name of German Austria. After the involvement of the Triple Entente, they soon changed the name to Republic of Austria, dropping thus the word 'German'. 
to agree to its acceptance as a UN member state under a provisional name, creating an ‘agonising situation' for the country (Vankovska 2010: 442; 450-452).

Although the applied phrase of 'Former Yugoslav' disappointed Macedonia due to the 'reduction' of its Macedonianness with the reference to the recent history of the country (Fidanovski 2018: 23), it did not satisfy Greece either since it still contained the term 'Macedonia'. Nevertheless, despite the mutual dissatisfaction with the UN Resolution of 1993, later both the Greek and the Macedonian sides preferred bilateral talks to resolve the dispute over bringing the question back to the UN General Assembly. The UN itself was dedicated to contribute to the resolution of the name dispute: in 1999, former US President's special envoy to mediate the resolution of the Macedonian issue, Matthew Nimetz, was appointed as a permanent mediator to the dispute. He proposed several names; however, it became obvious that no solution can be reached without the real commitment of the involved parties.

The main motivation for Macedonia to resolve the name dispute was getting rid of the Greek blockage in the EU and the NATO. Although conditionality, i.e. the fulfilment of certain economic, social, or political obligations as prerequisites for launching the accession talks, introduced by the EU, have generally been useful and have led to significant results in various Central European states, this was not the case for Macedonia. The Council of Ministers of the European Economic Community (EC) adopted a declaration in December 1991, containing a condition for former Yugoslav states to commit themselves to adopt constitutional and political guarantees ensuring that they will not use denominations implying territorial claims against a neighbouring EC state (Daskalovski 2013: 149-151; 160-161). Although the EC Arbitration Commission, better known as the Badinter Commission, pointed out early in 1992 that the name of the new country did not constitute any territorial claim to Greek territories (Vankovksa 2010: 449), due to the Greek membership, the EC was not in the position to take this opinion as a legally binding or authoritative one. Therefore, in its Lisbon Declaration of June 1992, the EC put omitting the word 'Macedonia' from the state's name as a condition for the recognition of independence. ${ }^{13}$ Despite Macedonia considered this as a hostile attitude resulting from the 'incapacity to understand and deal with the depth and seriousness' of the conflict (IlievskiTaleski 2009), the reason was the functioning of EC foreign policy based on collective decisions of the member states of the Community, including Greece.

While Skopje was fighting for the nation's identity and name, Athens rejected any reference to Macedonia in the name of the state at first. At the very beginning, Macedonia intended to keep its constitutional name of Republic of Macedonia in international relations and to discuss a suitable name to be employed only in bilateral relations with Greece. Athens saw this position, known as the 'dual

13 European Council in Lisbon (26-27 June 1992): Conclusions of the Presidency, Annex II, 24. https://ec.europa.eu/commission/presscorner/detail/en/DOC_92_3. Accessed on: 14 April 2020. 
formula', as an unlawful strategy aiming to avoid meaningful negotiations on the name issue despite the precise commitment to engage therein under Art. 5(1) of the Interim Accord (Messineo 2012: 176). The Greek position was firm: they were willing to accept only an erga omnes name, applying in all international relations, including third parties and multilateral organizations.

Later, Greece accepted the idea of using the word 'Macedonia' with a modifier; nevertheless, political modifiers were unacceptable for Athens since they were hardly distinctive. This ruled out such names as Democratic Republic of Macedonia or Independent Republic of Macedonia (Fidanovski 2018: 27-28). Greece argued for a geographical modifier that would show a hierarchical distinction, outlining the primordial feature of Greek Macedonia, securing that way the 'heritage' for Greece. Variations, such as the 'Republic of Macedonia (Skopje)', were not accepted either since many argued that the 'Skopje' component would disappear with time for practical reasons, leading to a situation when gradually the constitutional name would become internationally accepted (Ivanovski 2013). Athens also rejected such variations where the use of a proposed geographic modifier did not break up the phrase 'Republic of Macedonia', i.e. the Northern Republic of Macedonia proposed by Mr Nimetz (Fidanovski 2018: 28).

A major blow came for Athens in 2004, when the Bush administration recognized Macedonia under its constitutional name in the bilateral relations. The reason behind it was influencing the Macedonian population to support the modification of the law on municipality borders, required to the full implementation of the Ohrid Agreement of $2001^{14}$ and submitted to a referendum in 2004. Another event of great importance was giving Macedonia the status of EU candidate country in 2005; however, the accession talks did not start until March 2020.

In 2007, the Greek parliament unanimously adopted a resolution that the northern country's name could contain the word 'Macedonia', recognizing thus the fact that the name FYROM and all name variations until then contained the term as well. This happened during the preparations to the 2008 NATO summit in Bucharest, when the Slavic country was allegedly lamenting about putting the name 'Republic of Macedonia-Skopje' to a referendum (Fidanovski 2018: 35). Despite these developments, there was no progress in resolving the dispute, and Greece eventually vetoed Macedonia's application to the NATO in 2008, leaving Albania and Croatia the only two countries invited to join the military alliance one year later.

After the veto, the government in Skopje sued Greece, and the International Court of Justice (ICJ) made it clear in its verdict in 2011 that by objecting to the admission

14 The Ohrid Framework Agreement is an internal regulation of minority rights in Macedonia, signed on 13 August 2001 between the representatives of the then largest political parties and special representatives of the EU and the United States. The agreement was signed after the escalation of violence between the ethnically Albanian insurgents and the Macedonian Armed Forces in the 2001 conflict. 
of Macedonia to NATO Athens had breached one of its obligations under the 1995 Interim Accord. ${ }^{15}$ The Court saw clearly that the difference over the name was the decisive criterion for Greece to veto Macedonia's admission to NATO, in contrary to Art. 11(1) of the Interim Accord (Messineo 2012: 169-190). Some argued later that the ICJ decision offered a chance for NATO and the EU to overpass the name dispute and validate the political conditionality principle by admitting Macedonia into membership and starting negotiations under the UN provisional name (Daskalovski 2013: 149); yet this was not the case due to unanimity required in both organizations for enlargement. Even more, Greece clearly did not feel obliged by the judgement since in April 2013 Athens forwarded a message to its EU partners about its unwillingness to go along with an eventual decision on opening accession negotiations with Macedonia until the name dispute is resolved (Georgievski 2013: 17).

As mentioned earlier, the general view of the international community was that the stronger Greece was bullying the weaker Macedonia. Until 2018, altogether twothirds of the UN members, or more than 140 countries, including all permanent members of the Security Council but France, recognized Macedonia under its constitutional name. Yet, there was no crucial international pressure on Athens to make concessions to its neighbour to solve the name dispute. The only period when Macedonia intentionally weakened its position was that of the 'antiquization' that blurred the hitherto widespread 'bully-against-victim' international perception of the name dispute and enabled Athens to use the issue to argue that it had been right all along in fearing Macedonian irredentism (Fidanovski 2018: 31).

\section{The Prespa Agreement and its Implementation ${ }^{16}$}

The name dispute was a highly sensitive issue for the populations of the two countries. According to a survey in 2018, despite not considering FYROM as a threat - only 2 percent in 2016 and 2.5 percent in 2018 thought that the country could pose a threat to Greece -, the name dispute was qualified by almost all segments of the society as a 'very important' issue for Greece (Armakolas-Siakas 2018: 12-13). The non-compromising stance was high overall: 71.5 percent of the population. The stance was extremely high among rightist voters and in Northern Greece, and the share of those willing to compromise was a majority only among far-leftist and leftist voters. The main reason of rejecting the use of the name Macedonia was the

15 According to Art. 21(2) of the Interim Accord, the ICJ could be seized if 'any difference or dispute' arises between Greece and Macedonia with regard to 'the interpretation or implementation' of the Accord, except 'the difference referred to in Article 5, paragraph 1', which is the 'difference described in [Security Council] resolution [845(1993)] and in Security Council resolution 817(1993)'.

16 The agreement obliged the Parties to several adjustments in their legal system, which we will not address in this paper. 
fear from a future territorial aspiration, shared by 60.5 percent of the respondents and disagreed by only 31 percent (Armakolas-Siakas 2018: 15-17).

Macedonians saw the problem otherwise. According to a survey in 2010, some 67 percent of ethnic Macedonians rejected a name change, while among ethnic Albanians that share was only 17 percent. Seventy percent, a vast majority of the entire population, saw the name dispute as a Greek denial of Macedonian identity; among ethnic Macedonians, the share was 80 percent, but also 45 percent of ethnic Albanians agreed (Vankovska 2010: 465).

This is the reason why then Greek foreign minister Nikos Kotzias's declaration was a major step forward in October 2017. He made it clear that Macedonian language and nationality were not connected to the name dispute. ${ }^{17}$ This allowed the parties to reduce the symbolic implications of the dispute. Nevertheless, the restarting of diplomatic negotiations in early February 2018 triggered a sudden, emotionally charged uprising of a large part of the Greek society. ${ }^{18}$

Due to the shared commitment of the Greek and Macedonian governments, on 12 June 2018, Greek Prime Minister Alexis Tsipras announced they had a deal covering all the preconditions of the Greek party. The agreement was signed by the two foreign ministers in Psarades, Greece, on Lake Prespa on 17 June 2018. The ceremony was attended by the two prime ministers, UN Special Representative Matthew Nimetz, EU High Representative of the Union for Foreign Affairs and Security Policy Federica Mogherini, and European Commissioner for Enlargement and European Neighbourhood Policy Johannes Hahn, among others. After the meeting, Greek Prime Minister Tsipras crossed the border with his Macedonian counterpart for a lunch at Otoševo, North Macedonia. Since 1991, the independence of North Macedonia, this was the first time a Greek prime minister entered the country.

The Prespa Agreement, officially the Final Agreement or the Settlement of the Differences as Described in the United Nations Security Council Resolutions 817 (1993) and 845 (1993), the Termination of the Interim Accord of 1995, and the Establishment of a Strategic Partnership between the Parties, addressed both parties' concerns indeed. ${ }^{19}$ In the compromise, Macedonia changed its name to Republic of North Macedonia, in short: North Macedonia. This fulfilled the Greek demands to incorporate a geographic modifier between the words 'Republic' and 'Macedonia', and, according to Art. 1(3a) and Art. 1(5), it became an erga omnes name, used in

17 Kotzias: 'Talks on name dispute are not talks on identity'. European Western Balkans, 6 October 2017. https://europeanwesternbalkans.com/2017/10/06/kotzias-talks-name-dispute-arent-talksidentity/. Accessed on: 14 April 2020.

18 Tsekeris-Charalambos-Demertzis, Nicolas: Symbolic Identities: Understanding the Macedonia Name Dispute and Its Implications for EU Politics (22 October 2018). blogs.lse.ac.uk/ europpblog/2018/10/22/symbolic-identities-understanding-the-macedonia-name-dispute-anditsimplications-for-eu-politics/. Retrieved on: 7 April 2020, p. 2.

19 See the text at: https://s.kathimerini.gr/resources/article-files/symfwnia-aggliko-keimeno.pdf. Accessed on: 14 April 2020. 
both internal and international affairs. In exchange, Greece committed itself not to object to the application by or the membership of North Macedonia under the name and the terminologies agreed in the agreement.

The parties agreed on a technical and a political transition period for the change of the already existing documents and materials issued by Macedonia. In the case of official documents and materials of the public administration for international usage and of those for internal usage with the possibility of being used externally, they set a five-year term entering into force from the date of the agreement. Documents and materials issued for exclusively internal use shall be changed within five years after the opening of the relevant EU negotiation chapter.

The agreement, for instance, required North Macedonia to change the licence plates to ones with NM or NMK as the country code instead of MK as used after 2012. Skopje opted for the code NMK, introducing it into circulation in February 2019. The agreement contained that for all other purposes the country code will remain MK and MKD, as officially assigned by the International Organization for Standardization (ISO).

Symbolic questions play an important role in the agreement. For example, in Art. 3 , the parties confirmed their existing common border as an enduring and inviolable international border, while in Art. 4 they obliged not to amend their constitutions in such a way that could be interpreted as a threat to existing international borders. In Art. 6, they committed themselves to prohibit irredentist, revisionist, chauvinist, or hostile ideologies towards the other party, responding to Greece's long-term fear of a possible Macedonian irredentism.

They also agreed that the terms 'Macedonia' and 'Macedonian' have different meanings in the two countries. According to Art. 7(2), for Greece, they refer to its northern region, the people living there and their attributes 'as well as the Hellenic civilization, history, culture, and heritage of that region from antiquity to present day'. When the reference is made to North Macedonia, the terms denote its territory, language, people and their attributes, with their own history, culture, and heritage 'distinctly different from those referred to under Article 7(2)'.

Art. 7(4) recognized Macedonian language a member of the group of South Slavic languages, clarifying, however, that neither the language nor other attributes of North Macedonia are related to the ancient Hellenic civilization, history, culture, and heritage of the northern region of Greece. Nevertheless, art-s 7(2) and 7(4) combined, despite mentioning it explicitly, exclude any kin-state position of North Macedonia over the unrecognized Slavic-speaking minority of Greece by stating that the Macedonian language and identity denotes solely the territory, language, and identity of the Second Party, i.e. North Macedonia.

Furthermore, in Art. 8(2), North Macedonia undertook the obligation to review the status of monuments, public buildings, and infrastructures on its territory and to take corrective actions if they refer in any way to ancient Hellenic history and civilization constituting an integral component of the historic or cultural patrimony 
of Greece. North Macedonia committed itself to remove the Vergina Sun from all public sites and public usages on its territory within six months of the agreement entering into force. The Parties also agreed on setting up a Joint Inter-Disciplinary Committee of Experts on historic, archaeological, and educational matters.

In Art. 10, Greece and North Macedonia obliged themselves to upgrade their existing Liaison Offices in Skopje and Athens to an Embassy and the Office for Consular, Economic, and Commercial Affairs in Bitola and Thessaloniki to a General Consulate. They also agreed on the intensification of their bilateral relations through regular visits and by establishing a High-Level Cooperation Council of their Governments, jointly headed by their prime ministers. They committed themselves to strengthening economic cooperation through mutual investments, developing infrastructure, easing regulation on the movement of people and goods, and the construction, maintenance, and utilization of interconnecting natural gas and oil pipelines and with regard to renewable energy resources.

In case of a dispute related to the Prespa Agreement, in Art. 19, the Parties agreed to resolve that through peaceful means. If they cannot find a solution, they may turn to the Secretary General of the UN for his good offices to resolve the matter. If he is also unable to resolve the dispute, the Parties may submit the question to the ICJ.

On 20 June 2018, the North Macedonian parliament ratified the agreement, while the opposition party VMRO-DPMNE called the document the genocide of an entire nation ${ }^{20}$ and boycotted the session. On 25 June, the Greek foreign minister informed the EU and the NATO that Greece was no longer objecting to the country's Euro-Atlantic accession under the new name. Since North Macedonian President Gjorge Ivanov declined to sign the agreement, the parliament in Skopje voted for and supported the document again on 5 July. On 11 July, the NATO invited North Macedonia to start accession talks.

After the North Macedonian parliament's decision on 30 July to hold a nonbinding referendum on the agreement, the voters of North Macedonia were called to vote. The referendum, held on 30 September, asked the citizens whether they were 'for EU and NATO membership by accepting the Agreement between the Republic of Macedonia and the Republic of Greece'. ${ }^{21}$ The turnout was low, only 37 percent; however, an overwhelming majority, 91.5 percent of the voters supported the agreement. ${ }^{22}$ Since the North Macedonian legal system requires over 50 percent threshold to validate the results, both the government and the opposition, who called

20 (Видео) Стоилковски: Дали сега граѓаните ќе може да ја пеат химната „Денес над Македонија се раѓа”? (21 June 2018). https://makfax.com.mk/. Accessed on: 14 April 2020.

21 In this paper, we have no intention to enter into details about the Russian refusal of the Prespa Agreement and their involvement into the 'No' campaign in North Macedonia. Obviously, for Russia, the resolution of the name dispute was an extremely unfortunate event, especially after North Macedonia entered the NATO in March 2020.

22 Referendum 2018. https://referendum.sec.mk/Referendum/Results?cs=en-US\&r=r\&rd=r1\&eu= All\&m=All. Accessed on: 14 April 2020. 
for a boycott, could claim victory. The highest turnouts came in predominantly Albanian districts; however, not high enough to compensate the absence of the majority of the ethnic Macedonians. ${ }^{23}$

In October 2018, after the political debate over the Prespa Agreement started in the Parliament in Skopje, US Assistant Secretary of State Wess Mitchell expressed the US's disappointment over the VMRO-DPMNE's refusal of the agreement urging him and his party 'to set aside partisan interests to advance our shared strategic interest and secure a brighter future' for the country. ${ }^{24}$ The renaming process started on 19 October, after a two-thirds majority of the North Macedonian parliament agreed to it, and ended on 11 January 2019 with approving all the constitutional amendments required by the Prespa Agreement, again with a two-thirds majority. Securing this majority was a great challenge to Prime Minister Zaev, who had to ensure the support of all the Albanian parties and that of several opposition MPs..$^{25}$

Thereafter, the Greek ratification could be next, which needed a simple majority in the Parliament in Athens. There were mass protests in Greece on 4 February 2018 during the negotiation process, during which the most used hashtags were \#MacedoniaIsGreek and \#Syllalitirio (demonstration, rally) (Zeri-TsekerisTsekeris 2018: 10-11). In October 2018, just months after the signing of the Prespa Agreement, Greek Foreign Minister Nikos Kotzias resigned because Prime Minister Tsipras failed to protect him against the attacks of a cabinet member from a junior coalition member party opposing the agreement. ${ }^{26}$ The minister in question and his party, the Independent Greeks, eventually left the government on 13 January 2019, just after the ratification of the agreement by the Parliament in Skopje. In January 2019, there were again mass protests against the Greek ratification, showing the continuing Greek popular rejection; ${ }^{27}$ however, after a 38-hour-long debate during which a total of 200 MPs spoke out of the 300, the Greek Parliament adopted the Prespa Agreement on 25 January 2019. ${ }^{28}$

23 Albanian Vote Not Crucial in Macedonia Referendum Shortfall (3 October 2018). https:// balkaninsight.com/2018/10/03/albanian-vote-not-crucial-in-macedonia-referendumshortfall-10-02-2018/. Accessed on: 14 April 2020.

24 The letter can be accessed at: https://balkaneu.com/wess-mitchell-to-vmro-dpmne-leadermickoski-we-are-disappointed-with-you/. Accessed on: 14 April 2020.

25 Macedonia MPs Pass Amendments to Change Country's Name (11 January 2019). https://balkaninsight.com/2019/01/11/macedonia-parliament-backs-first-of-four-nameamendments-01-11-2019/. Accessed on: 14 April 2020.

26 Greek PM Accepts Kotzias Resignation, Takes Over As Foreign Minister (17 October 2018). https://www.ekathimerini.com/233729/article/ekathimerini/news/greek-pm-accepts-kotziasresignation-takes-over-as-foreign-minister. Accessed on: 14 April 2020.

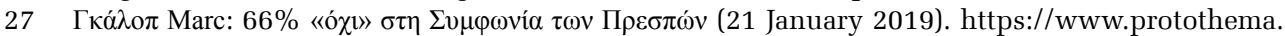
gr/politics/article/857064/galop-marc-66-ohi-sti-sumfonia-ton-prespon/. Accessed on: 14 April 2020. Poll Shows Six in 10 Oppose Name Deal (24 January 2019). https://www.ekathimerini. com/236974/article/ekathimerini/news/poll-shows-six-in-10-oppose-name-deal. Accessed on: 14 April 2020.

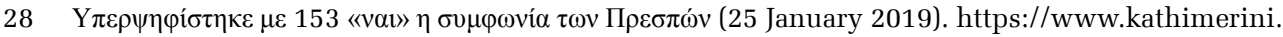


The resolution of the name dispute opened the way for North Macedonia. After the termination of the ratification process, prime ministers Alexis Tsipras and Zoran Zaev were nominated for the 2019 Nobel Peace Prize; however, they were not awarded. Nevertheless, accession to international organizations became possible and has already brought fruits: on 27 March 2019, the NATO welcomed North Macedonia as its $30^{\text {th }}$ member state. On 26 March 2020, the European Council, comprising the head of states or governments of the EU Member States, decided to open accession talks with Albania and North Macedonia. ${ }^{29}$

The agreement has also rocketed bilateral trade between North Macedonia and Greece. Just in 2018, the total value of the trade between the two countries recorded an increase of 15.8 percent, with Greek exports to North Macedonia rising a significant 19.1 percent compared to the previous year. ${ }^{30}$ Surprisingly, however, the name dispute did not impede Greece to invest in Northern Macedonia even before the Prespa Agreement. In 2018, Greece was the third country in terms of stocks, ${ }^{31}$ about 10 percent of all FDI. Greek companies have invested in the financial, telecommunication, energy, and food processing sectors; however, the rate of reinvestment is low since most of the profits are repatriated back to Greece. ${ }^{32}$

\section{Conclusions}

Sensitivities always have influence on international relations. The Balkan Peninsula is a particular place in this sense due to the centuries-long foreign occupations and the mixed ethnic composition of states in the region. Not so many years ago, the change of the borders and violent conflicts were part of everyday life in the Balkans. Long-standing fears from neighbouring states' territorial aspirations and from the possible aspirations of various ethnic groups within states have led to such sensitivities that might be unimaginable in other parts of the world.

gr/1006678/article/epikairothta/politikh/yperyhfisthke-me-153-nai-h-symfwnia-twn-prespwn. Accessed on: 14 April 2020.

29 Council Conclusions on Enlargement and Stabilisation and Association Process - Albania and the Republic of North Macedonia (25 March 2020). https://www.consilium.europa.eu/en/ press/press-releases/2020/03/25/council-conclusions-on-enlargement-and-stabilisation-andassociation-process/. Accessed on. 14 April 2020.

30 Greece Becomes the Second Largest Investor in North Macedonia (2 April 2019). https:// greece.greekreporter.com/2019/04/02/greece-becomes-the-second-largest-investor-in-northmacedonia/. Accessed on: 14 April 2020.

31 Foreign Direct Investment (FDI) in North Macedonia. https://www.nordeatrade.com/en/explorenew-market/north-macedonia/investment?vider_sticky=oui. Accessed on: 14 April 2020.

32 Prospects for Macedonian-Greek Economic Relations after the Prespa Agreement (2 September 2019). https://china-cee.eu/2019/09/02/north-macedonia-economy-briefing-prospects-formacedonian-greek-economic-relations-after-the-prespa-agreement/. Accessed on: 14 April 2020. 
The Macedonian name dispute also rooted in fears hardly understandable. This, however, did not diminish their importance since international relations are based on states having their own agendas, plans, perceptions, and fears obviously. What made this dispute outstanding was the efficiency of the Greek blockade on any attempts of Macedonia, today's North Macedonia, to join the EU and the NATO. The international community tried to ease the tensions between the two countries, yet without their commitment there was no chance for a resolution. It was a fortunate coincidence that in 2017 and 2018 both countries were governed by such coalitions that had their chief political force a party devoted to resolving the name dispute, considering that a hurdle belonging to the past and to the sphere of non-rational myths, and also that they managed to reach a compromise. This development resulted in the signing of the Prespa Agreement, a historical document to end the name dispute.

One could say that only Macedonia had to accept a compromise, while Greece obtained everything it wanted. Nevertheless, the 2018 agreement is not a Macedonian defeat, and the success of Prespa can be measured by the fast realization of the long-time Macedonian desire to join the NATO, which happened in March 2020, or by being given the green light to start the accession negotiations with the EU. The agreement is not a defeat also in the sense that Macedonia secured its name, although with a geographic modifier - the Republic of North Macedonia -, and Greece recognized the existence of a Slavic Macedonian language, culture and the Macedonian citizenship as well. Skopje had to renounce in turn the cultural heritage of ancient Macedonia that, in fact, has no real connection to the present population of the country.

The question arising after Prespa is the following: can North Macedonia turn to be a success story? We saw the circumstances after the independence of 1991, and we mentioned briefly the ethnic clashes of 2001. Its accession to the NATO and the possibility of North Macedonia to become a Member State of the EU can strengthen social cohesion within the state, but a lot depends on the social and, especially, on the political élite of the state: they cannot point at Greece anymore for failures. The Prespa Agreement is a solution in itself, yet it is also an opening to a better North Macedonia, in which success or failure will be influenced by internal factors more than before.

\section{References}

AGELOPOULOS, Giorgos. 1995. Perceptions, Construction and Definition of Greek National Identity in Late Nineteenth-Early Twentieth Century Macedonia. Пєрıобıкó Balkan Studies 36(2): 247-263.

AHN, Byeongsun. 2017. Lights and Shadows of Social Movements: Constructing a Collective Identity in Post-Socialist Macedonia. Südosteuropa Mitteilungen 57(4-5): 40-53. 
ARMAKOLAS, Ioannis-SIAKAS, George. 2018. What's in a Name? Greek Public Attitudes towards the 'Name Dispute' and the Former Yugoslav Republic of Macedonia in 2018. Research Report. Athens: Hellenic Foundation for European and Foreign Policy.

BALOGH, Ádám. 2002. Lakosságcsere Görögország és Törökország között 1914-ben. Világtörténet (1-2): 37-46.

2011. A görög külpolitika „újjászületése” a macedón kérdésben. Világtörténet (3-4): 203-211.

BINTLIFF, John. L. 2003. The Ethnoarchaeology of a 'Passive' Ethnicity. In: Brown, K.S.-Hamilakis, Yannis (eds), The Usable Past: Greek Metahistories. New YorkOxford: Lexington Books. 129-144.

BITTER, Sabine-WEBER, Helmut. 2018. Making Ruins. In: Tortell, PhilippeTurin, Mark, Young, Margot (eds), Memory. Vancouver: Peter Wall Institute for Advanced Studies, University of British Columbia. 39-48.

DASKALOVSKI, Židas. 2013. The Macedonian Name Dispute and the Principle of Conditionality. In: Jovanović, Srđan M.-Stančetić, Veran (eds), History and Politics in the Western Balkans: Changes at the Turn of the Millennium. Belgrade: Center for Good Governance Studies - OPAL Edition, (1-2).

FIDANOVSKI, Kristijan. 2018. What's in a Name? Possible Ways Forward in the Macedonian Name Dispute. Slovo 31(1): 18-44.

GEORGIEVSKI, Sašo. 2013. The Judgment of the International Court of Justice of 5 December 2011 and the Greek-Macedonian 'Difference over the Name': Does the ICJ's Judgment Affect the Pending Diplomatic Dispute Settlement Process? Iustinianus Primus Law Review 4(2): 1-21.

HATZIDIMITRIOU, Constatine G. 1993. Distorting History. Balkan Studies: A Biannual Publication of the Institute for Balkan Studies 34(2): 315-351.

ILIEVSKI, Zoran-TALESKI, Dane. 2009. Was the EU's Role in the Conflict Management in Macedonia a Success? Ethnopolitics 8(3): 355-367.

IVANOVSKI, Hristijan. 2013. The Macedonia-Greece Dispute/Difference over the Name Issue: Mitigating the Inherently Unsolvable. New Balkan Politics 14: 48-80. KALAMPALIKIS, Nikos. 2019. A Lasting Symbolic Threat: The Dispute over the Name Macedonia in Greece. In: Jodelet, D.-Vala, J.-Drozda-Senkowska, E. (eds), Societies under Threat. Paris: Springer, Cham. 101-112.

KARPAT, Kemal H. 1985. Ottoman Population, 1830-1914: Demographic and Social Characteristics. Madison: University of Wisconsin Press.

KOFOS, Evangelos. 2001. Greek Policy Considerations over FYROM Independence and Recognition. In: Pettifer, James (ed.), The New Macedonian Question. London: Palgavre Macmillan. 226-263.

LIAKOS, Antonis. 2008. Hellenism and the Making of Modern Greece. In: Zacharia, Katerina (ed.), Hellenism - Culture, Identity, and Ethnicity from Antiquity to Modernity. Hampshire: Ashgate Varionum. 201-235. 
MANOS, Ioannis. 2010. On Being Macedonian: Social and Cultural Constructions of Identity in Greek Macedonia. In: Stefanidis, Ioannis D.-Vlasidis, VlasisKofos, Evangelos (eds), Macedonian Identities Through Time - Interdisciplinary Approaches. Thessaloniki: Epikentro. 258-272.

MESSINEO, Francesco. 2012. Maps of Ephemeral Empires: The ICJ and the Macedonian Name Dispute. Cambridge Journal of International and Comparative Law (1)1: 169-190.

STEFANOVSKA, Jasna-KOŽELJ, Janez. 2012. Urban Planning and Transitional Development Issues: The Case of Skopje. Macedonia Urbani Izziv 23(1): 91-100. VANKOVSKA, Biljana. 2010. David vs. Goliath: Macedonia's Position(s) in the 'Name Dispute' with Greece. Südosteuropa 58(3): 436-467.

VOSKOPOULOS, George. 2006. The Geographical and Systemic Influences on Greek Foreign Policy in the Balkans in the 1990s. Perspectives (26): 69-90.

ZERI, Persefoni-TSEKERIS, Charalambos-TSEKERIS, Theodore. 2018. Investigating the Macedonia Naming Dispute in the Twitter Era: Implications for the Greek Identity Crisis. GreeSE Papers Hellenic Observatory Discussion Papers on Greece and Southeast Europe 127(July). 